\title{
Economic growth and human development in Latin America
}

\section{Gustav Ranis}

Henry R. Luce Director

of the Yale Center for

International and Area

Studies (YCIAS),

Frank Altschul Professor

of International Economics,

Yale University

gustav.ranis@yale.edu

Frances Stewart

Director,

Queen Elizabeth House

Oxford

frances.stewart@queen-

elizabeth-house.oxford.ac.uk
The paper explores the two-way links between human development and economic growth in Latin America. Economic growth is likely to advance human development as the resource base expands, while higher human development generates greater economic growth as healthier and more educated people contribute to improved economic performance. Regression analysis shows quite strong connections from human development to economic growth in Latin America, but the economic growth to human development relationship is much weaker than that indicated by worldwide evidence, probably due to the disruptive impact of the debt crisis. Case studies of successful and unsuccessful countries show that human development success was due to good economic performance combined with high social expenditure; failures were associated with conflict, natural disasters and harsh adjustment policies. Exploration of country behaviour over time confirms that priority should be given to human development to reach a virtuous cycle of growth and higher human development. 


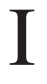

\section{Introduction}

There is a strong case to be made for regarding human development rather than economic growth as the ultimate objective of human activity. Human development has been defined as enlarging people's choices in a way which enables them to lead longer, healthier and fuller lives. ${ }^{1}$ This is a very broad definition of human development, and can include a great variety of choices, for example in the political and cultural dimensions. In this paper we focus on a narrow subset of choices -those directed specifically at health and education- which are among the basic preconditions for choice in other dimensions. This paper is in the spirit of much of the work of Al Berry, whose major concern has been to move beyond growth of per capita income to focus rather on its distribution, with the objective of improving the lives of the poor. ${ }^{2}$

In a previous paper (Ranis, Stewart and Ramírez, 2000), we explored the links between human development (defined in this rather restricted fashion) and economic growth, both theoretically and empirically. Clearly, there exists a strong two-way connection between the two. On the one hand, economic growth provides the resources to permit sustained improvements in human development. On the other, improvements in the quality of the labour force constitute an important contribution to economic growth. While these general connections are readily accepted, one needs to understand the links in more depth for this to be of much use in policy formulation.
In particular, one needs to know whether all forms of economic growth promote human development, or whether there are particular patterns of economic growth which are more conducive to human development; equally, whether all forms of human development promote economic growth, or whether there are specific types which are more conducive to promoting such growth; and whether we can say anything useful about priorities if a choice is necessary: for example, should human development be promoted before economic growth, or can we delay the achievement of human development while promoting economic growth?

In order to answer these questions we explored the theoretical links and then analysed them empirically, drawing on cross-country data from all developing regions of the world. The exercise came to quite strong conclusions about the questions just posed above. In this paper, we aim to investigate how well our general findings apply in the Latin American context, and what policy conclusions are to be derived from the Latin American experience.

The next section of the paper (section II) summarizes the findings of our earlier work. Section III presents some econometric estimates for Latin America, comparing them with the earlier global findings, and section IV reports on some country cases in Latin America which have been particularly successful or unsuccessful. Finally, section V presents some brief conclusions. $\square$ This version was originally presented at the conference in honour of Professor Albert Berry on 'The Social and Economic Effects of Globalization and Liberalization on the Labour Market and Income Distribution', organized by the University of Toronto on 19 and 20 April 2002. We wish to express our thanks to Tavneet Suri, for her outstanding support, and also to Prateek Tandon for his valuable assistance.

\footnotetext{
${ }^{1}$ The first UndP Human Development Report stated that: "The basic objective of development is to create an enabling environment for people to enjoy long, healthy and creative lives" (UNDP, 1990, p. 9), and defined human development as "a process of enlarging people's choices" (p. 10).

${ }^{2}$ For an early example see Berry and Urrutia (1976); for a much more recent one, see Berry (ed., 1998).
} 
II

\section{Human development and economic growth: findings from the previous study}

We view human development as the central objective of human activity and economic growth as potentially a very important instrument for advancing it. At the same time, achievements in human development themselves can make a critical contribution to economic growth. There are thus two distinct causal chains to be examined: one runs from economic growth to human development, as the resources from national income are allocated to activities contributing to human development; the other runs from human development to economic growth, indicating how human development, as well as being an overriding objective, helps increase national income. The two chains are pictured in figure 1 .

\section{Chain A: from economic growth to human development}

From a review of the literature on the determinants of human development, it appears that the main links in the chain from economic growth to human development relate to:

FIGURE 1

Human development and economic growth

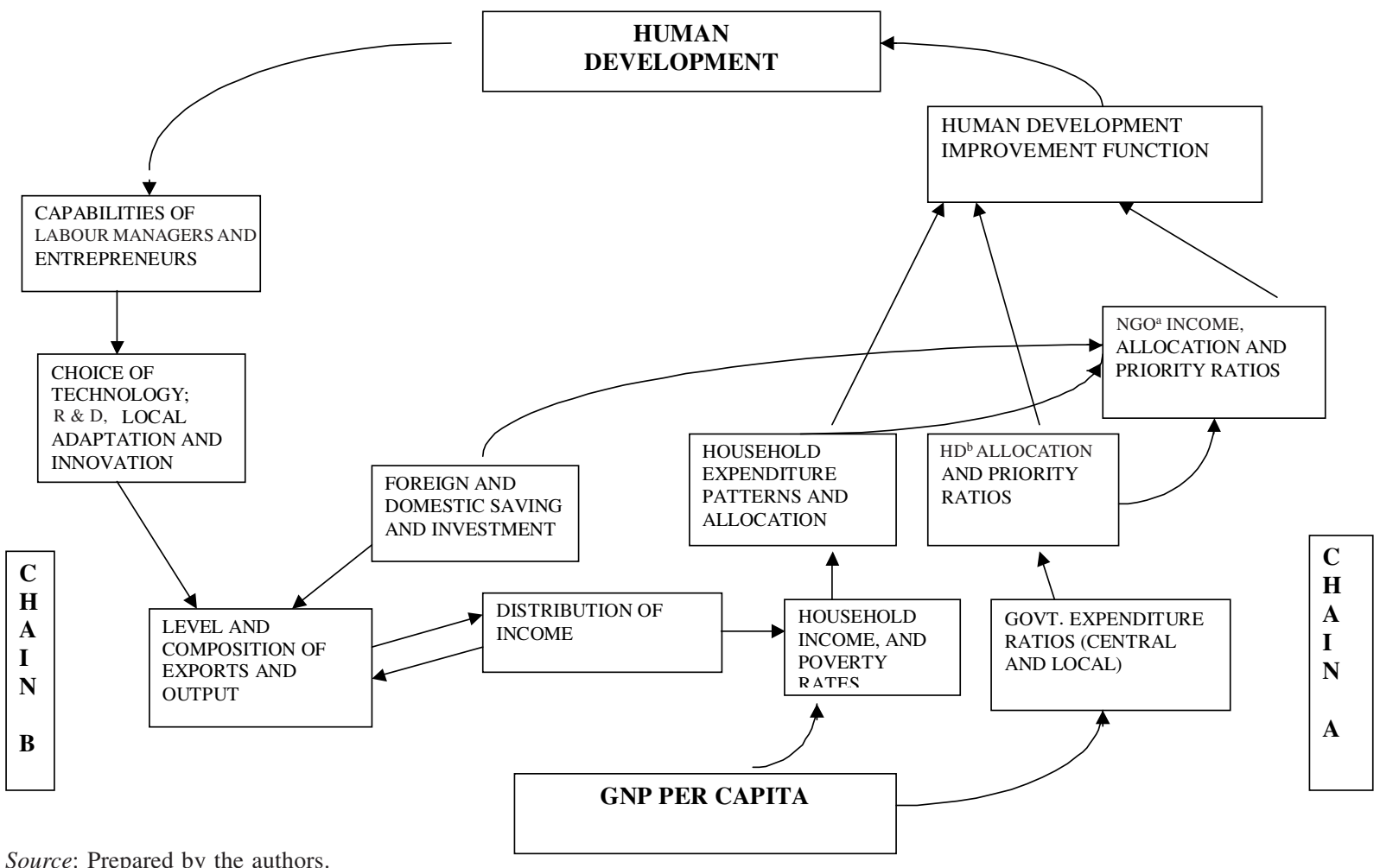

Source: Prepared by the authors.

a NGO: Non-governmental organization.

${ }^{\mathrm{b}}$ HD: Human development. 
a) The distribution of GDP between households and government, since each performs vital, if different, roles in generating conditions favourable for human development. Civil society -for example, through community organizations and other NGOsalso plays a role. These organizations' share of national resources depends on the decisions of government and households on how much to allocate to them.

b) The distribution of income among households, as income going to poorer households is more likely to enhance our restricted concept of human development (education, health), since deficiencies are greatest among such households.

c) Households' propensity to spend their after-tax income on items which contribute most directly to the promotion of human development in poor countries, such as food, education and health services. A major determinant in this respect appears to be the share of income controlled by females.

d) With regard to the government, the allocation of resources for improving human development is a function of total public sector expenditure, of how much of this flows to the human development sectors, and of the way in which it is allocated within these sectors. This can be expressed in the form of three ratios $^{3}$ : the public expenditure ratio, defined as the proportion of GNP spent by the various levels of government; the human development allocation ratio, defined as the proportion of total government expenditure going to the human development sectors; and, finally, the human development priority ratio, defined as the proportion of total human development sector expenditure going to 'priority areas'. The precise definition of what constitutes a 'priority area' varies according to a country's stage of development, rendering this third ratio more arbitrary and difficult to measure than the other two. Within the health and education sectors, however, some expenditures are clearly much more productive in terms of achieving advances in human development than others: for example, basic education, especially in countries at an early stage of development, is generally recognized to have a larger impact on human development than tertiary education.

\footnotetext{
${ }^{3}$ See Human Development Report 1991.
}

e) The activities of NGOs or other sectors of civil society activity are likely to promote human development. Information on this is more scattered, but NGO expenditures appear to be typically heavily oriented towards human development objectives (e.g. generating incomes for the poor, and school, nutrition and health projects). In most contexts, NGOs play a supplemental or even marginal role, but in a few areas -such as the Bangladesh Rural Advancement Committee (BRAC) and the Grameen Bank in Bangladesh, the Harambee Schools in Kenya and the 'Comedores Populares' in Peru, for example- they appear to represent a major source of human development enhancement (Riddell et al., 1995).

f) The effectiveness of these various expenditures in raising human development levels is, of course, an important consideration. Expenditures on human development inputs are clearly not objectives in themselves, but rather constitute instruments for achieving advances in various dimensions of basic well-being. A further important link in Chain A is what type of measure is most productive at what level of development, and how different combinations bring about a change in human development. We call this link in the chain the human development improvement function; it resembles a production function in that it relates the inputs into human development, such as public expenditure on health services or potable water, to the human development objective of achieving better health.

It is clear from this discussion of the various links in the economic growth to human development chain that, in general, we would expect important causal connections to exist between the economy and human development achievements, but these connections are not automatic: the strength of the links in Chain A varies according to a large range of factors, including the structure of the economy, the distribution of income and assets, and the policy choices made.

\section{Chain B: from human development to economic growth}

Turning our attention to this second chain, there is strong empirical support for the view that as people become healthier, better nourished and more highly educated they contribute more to economic growth. More specifically, both micro- and macro-level research show that: 
a) Extending primary education raises the productivity of both rural and urban workers. In agriculture, education raises productivity among farmers using modern technologies, with less impact, as might be expected, among those using traditional methods. ${ }^{4}$ Education is also an important contributor to technological capability and technical change in industry.

b) Improved health and nutrition have been shown to have direct effects on labour productivity, especially among poorer individuals. ${ }^{5}$ Morbidity has a negative impact on labour productivity, as shown, for example, by studies in Ghana and Côte d'Ivoire (Schultz and Tansel, 1993). In some contexts the evidence indicates that the productivity effects arising from health and nutrition are even larger than from formal schooling, although the impact of education has been much more emphasized in the development literature.

c) Secondary education, including vocational, facilitates the acquisition of skills and managerial capacity.

d) Tertiary education supports the development of basic science, the appropriate selection of technology imports, their domestic adaptation and the development of indigenous technologies.

e) Secondary and tertiary education represent critical elements in the development of key institutions in the areas of government, law and the financial system, among others, which are all essential for economic growth.

f) From a macro perspective, the "new growth theories" aim to endogenize technical progress by incorporating some of these same effects, with emphasis on education, learning by doing and $\mathrm{R}$. and D. A number of empirical studies have shown the positive effect of education on economic growth at the macro level, with the size of this effect varying according to the measure of education and the particular macro growth model adopted. ${ }^{6}$

g) Education affects the nature and growth of exports, which in turn affects the aggregate growth rate. It has been argued that even 'unskilled' workers in a modern factory normally need the literacy, numeracy and discipline which are acquired in

\footnotetext{
${ }^{4}$ See Schultz (1975), Welch (1970), Rosenzweig (1995), and Foster and Rosenzweig (1994).

${ }^{5}$ See surveys in Behrman, 1993 and 1996.

${ }^{6}$ For example, Barro (1991) and Barro and Lee (1993 a and b).
}

primary and lower secondary school (Wood, 1994). Studies have shown a significant positive correlation between the growth of manufactured exports and the growth of GDP. ${ }^{7}$

h) Education can also affect per capita income growth via its impact on the denominator, i.e., population growth. Many studies have shown a negative correlation between female schooling and fertility (Ainsworth, Beegle and Nyamete, 1995).

i) Increasing basic education has been shown to lead to more equal income distribution (Psacharopoulos and others, 1992, p. 48), and recent studies suggest that a more equal distribution of assets and income has a positive effect on economic growth. ${ }^{8}$ As in Chain A, the strength of the various links in Chain $B$ varies and there is no automatic connection between an improved level of human development and increases in per capita GDP. Education, health and nutrition alone, of course, cannot transform an economy. The quantity and quality of investment, both domestic and foreign, together with the overall policy environment, represent other important determinants of economic performance. Income distribution again appears to be important in Chain B, as in Chain A.

\section{Empirical findings}

Our earlier empirical work used cross-country regressions covering 35 to 76 developing countries, according to the availability of data for particular variables, for the 1960-1992 period. We tested the following hypotheses, derived from the analysis of Chain A summarized above:

Human development improvement would be greater:

A1: the higher the economic growth;

A2: the lower the proportion of the population below the poverty line; for a given level of per capita GDP, this means the more equally income is distributed;

A3: the more income households allocate to human development at a given income level; this may be related both to the level of female education and to the extent of female control over income within the household;

\footnotetext{
${ }^{7}$ For example, Michaely (1977), Krueger (1978), Ram (1985), Rana (1988) and Edwards (1993).

${ }^{8}$ See Alesina and Rodrik (1994), Alesina and Perotti (1994), Persson and Tabellini (1994) and Birdsall, Ross and Sabot (1995).
} 
A4: the higher the proportion of GDP devoted to social expenditure by the government.

Using the change in human development, proxied

by life expectancy shortfall reduction, 1970-1992, as the dependent variable, for Chain A we found that:

a) Per capita GDP growth proved significant and quite strong in all of the equations, with higher growth of per capita income leading to better human development performance. According to one equation, a one percentage point increase in the average growth rate of per capita GDP was estimated to reduce life expectancy shortfall by more than 3 percentage points over the period.

b) The share of national resources going to social expenditure almost always proved significantly positive. For every percentage point increase in the average share of GDP invested in health and education (lagged), the life expectancy shortfall decreased by about 1.75 percentage points.

c) The initial female primary enrollment rate had a significant but small impact on the subsequent rate of improvement in life expectancy. We attributed this to the impact on household behaviour of female income, knowledge and control within the household.

d) Contrary to expectations, a more equal distribution of income did not seem to advance human development.

e) Both the African and Latin American dummies were negative and significant throughout, as we might have expected, given that the comparator was highly successful East Asia. In each case the coefficient was quite small.

For Chain B, we tested the following hypotheses: GDP growth would be higher:

B1: the higher human development;

B2: the higher the investment rate;

B3: the more equal the distribution of income.

Using per capita GDP growth, 1970-1992, as the dependent variable, for Chain B we found that:

a) Measures of the initial level of human development invariably proved significant, although with low coefficients.

b) The change in life expectancy (1962-1982) was positive and significant in all cases but one.

c) The domestic investment rate was always significant, except when the regional dummies were included.

d) The lagged income distribution variables virtually all gave results with the expected sign (i.e., more equal income distribution is associated with higher economic growth), and were almost always significant, except when the regional dummies were included.

e) Regional dummies for Latin America were significantly negative in every case and, in one case, also for Africa.

In summary, the two chains, taken together, showed a significantly positive effect of economic growth on human development and a significantly positive effect of human development on economic growth.

\section{Virtuous and vicious cycles and lopsided development}

The existence of two chains linking human development and economic growth was thus strongly supported by our results. This means that an economy may be on a mutually reinforcing upward spiral, with high levels of human development leading to high growth, and high growth in turn further promoting human development. Conversely, weak human development may result in low growth and consequently poor progress towards human development improvement.

Following this reasoning, we classified country performance into four categories: virtuous cycles, vicious cycles, and two types of lopsidedness, i.e., lopsided with strong human development but weak economic growth (called "human development lopsidedness"), and lopsided with weak human development but strong economic growth ("economic growth lopsidedness"). In the virtuous cycle case, good human development enhances growth, which in turn promotes human development, and so on. In the vicious cycle case, poor performance in human development tends to lead to poor growth performance, which in turn depresses human development achievements, and so on. The stronger the linkages in the two chains described above, the more pronounced the cycle of economic growth and human development, either in a positive or dampening direction. Where linkages are weak, cases of lopsided development may occur. On the one hand, good economic growth may not bring about good human development if, for example, there are weak linkages such as a low social expenditure ratio; on the other hand, good human development performance may not generate good economic growth if there is a dearth of complementary resources, such as low investment rates. Such cases of lopsided development are, however, unlikely to persist. Either the weak partner in the cycle eventually acts as a brake 
FIGURE 2

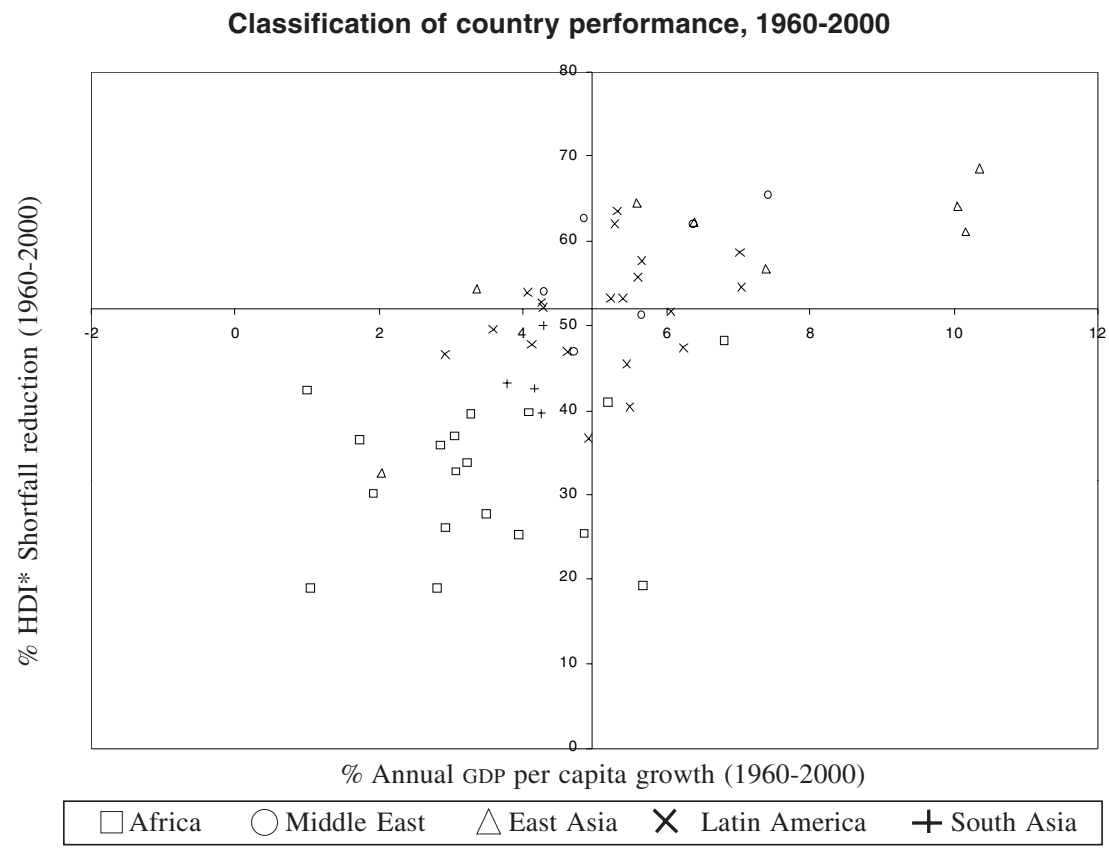

Source: Prepared by the authors.

on the other partner, leading to a vicious cycle case, or, if the linkages are strengthened over time, possibly by policy change, a virtuous cycle results.

For the purpose of classifying country performance empirically, we compared the performance of each country to the average of all developing countries. It is important to explore how a country moves from one category to another over time. In our earlier work, both lopsided categories proved very impermanent. Indeed, the most interesting finding from this work was that none of the countries that started as economic growthlopsided were able to move from there to the virtuous cycle category: all fell back to the vicious cycle (poor human development, poor economic growth) category. Thus, our previous global analysis suggested that it is not possible to move to a virtuous cycle via economic growth-lopsidedness, as this proved a dead end. In contrast, some countries which started as human development-lopsided did manage to move into the virtuous cycle category.

\section{III}

\section{The Latin American perspective}

The global picture, now extended to 1960-2000, is presented in figure 2 , where the vertical dividing line represents the average human development shortfall reduction for the developing world as a whole and the horizontal dividing line represents the average per capita GDP growth rate -both weighted by population. This figure indicates that Latin American countries are concentrated in the human development-lopsided and vicious cycle quadrants. This is in sharp contrast to East Asia, which is mainly in the virtuous cycle category and Sub-Saharan Africa, which is mainly in the vicious cycle category. In figure 2 , the measure of human development adopted -the human development index $\left(\mathrm{HDI}^{*}\right)$ - is the same as the most recent formula adopted by the UNDP for its own human development index (HDI), ${ }^{9}$ except it excludes the income component, since

\footnotetext{
9 The UNDP HDI, as currently constituted, includes life expectancy at birth, calculated as an index with a minimum of 25 years and a maximum of 85 years; an education component made up of adult literacy and the combined primary, secondary and tertiary gross enrolment rate; and a measure of real income weighted according to income level at purchasing power parity (see UNDP, 2001).
} 
FIGURE 3

Classification of country performance, Latin America, 1960-2000

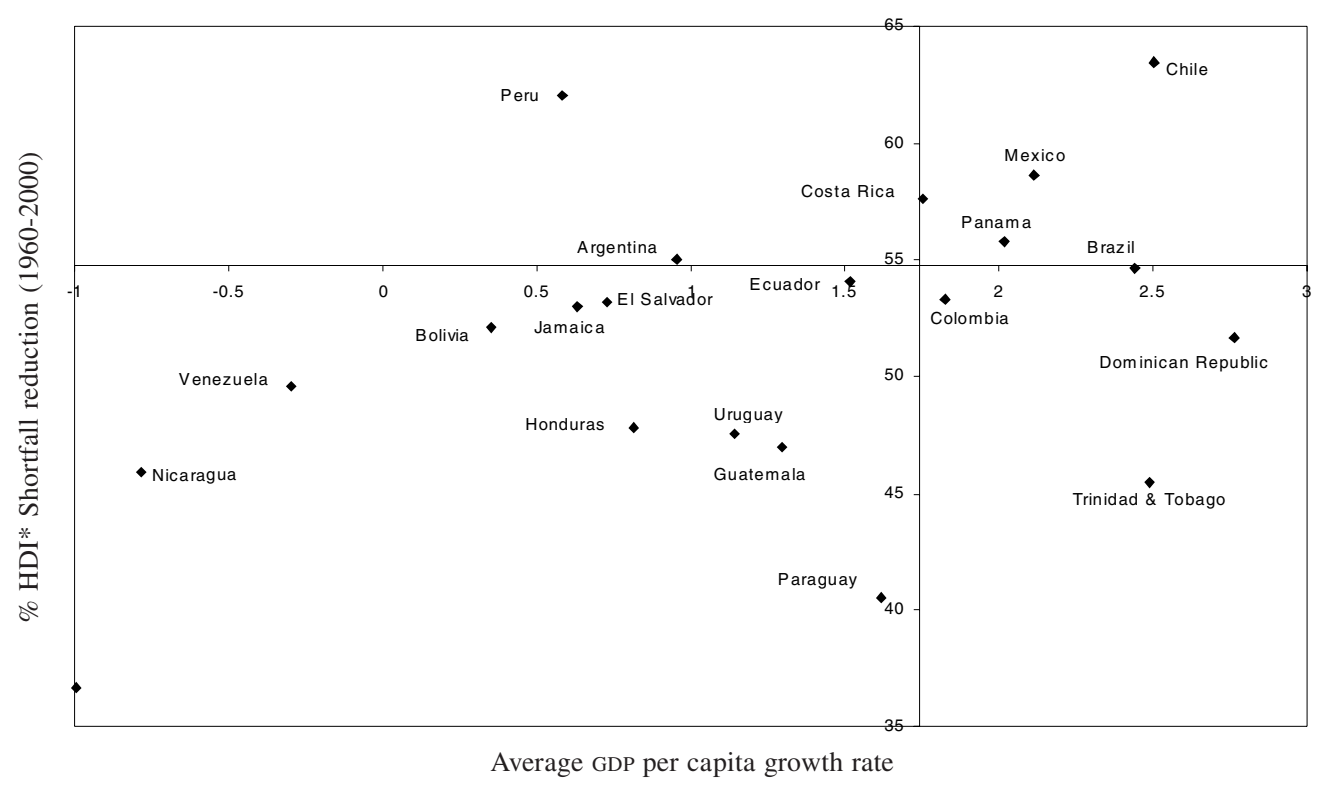

Source: Prepared by the authors.

we do not want income to appear as part of both human development and economic growth.

The position of Latin America relative to other regions is due in part to the particularly heavy impact of the 1980s debt crisis on the region. As is well known, this decade is often termed the "lost decade". When we come to focus on the Latin American countries relative to each other - particularly in the 1980 s- this means that negative growth performance over that decade is the norm, so that a country such as Mexico, which had falling per capita income in the 1980s, may nonetheless appear in the virtuous quadrant.

When we compare countries across Latin America for the 1960-2000 period, classified only according to the region's average performance (figure 3 ), four countries appear in the virtuous category -Chile, Costa Rica, Mexico and Panama. The majority of Latin American countries fall in the vicious category, with a small number in the human development- or economic growth-lopsided quadrants.

Again, it is enlightening to investigate country movements over time. Table 1 shows the positions of the Latin American countries decade by decade. We classified them, in terms of growth and HDI* shortfall reduction, into vicious, virtuous, human developmentlopsided and economic growth-lopsided quadrants, noting how the country classification shifts from decade to decade. These transitions are based on how countries fare relative to the Latin American (not the world) average. We find that countries' positions fluctuate over time for a variety of both general and country-specific reasons. In contrast to the global picture, Latin American countries move more frequently in and out of the virtuous and vicious categories. This is partly due to the smaller number of countries involved and the greater similarity among countries in a single region, which means that small changes can lead to switches in classification, and is also partly because the larger incidence of exogenous shocks is likely to lead to more changes of this type.

Most importantly, the Latin American analysis reinforces our earlier conclusion: that it is not possible to move from economic growth-lopsided to the virtuous category. In contrast, countries which are human development-lopsided are frequently seen to move into the virtuous category, while countries in the economic growth-lopsided quadrant tend to return to the vicious cycle. This has strong implications for the sequencing of policy, suggesting that, in contrast to the pattern often advocated, it is not possible to put growth first and worry about human development later, because this will actually undermine both growth and human 
Latin America: Classification of countries according to changes

in human development (HD) and economic growth (EG), 1960-2000

\begin{tabular}{|c|c|c|c|c|}
\hline Country & $1960-1970$ & $1970-1980$ & $1980-1990$ & $1990-2000$ \\
\hline Argentina & HD-lopsided & HD-lopsided & HD-lopsided & Virtuous cycle \\
\hline Bolivia & Vicious cycle & Vicious cycle & Vicious cycle & Vicious cycle \\
\hline Brazil & EG-lopsided & EG-lopsided & EG-lopsided & Vicious cycle \\
\hline Chile & HD-lopsided & HD-lopsided & Virtuous cycle & Virtuous cycle \\
\hline Colombia & HD-lopsided & HD-lopsided & Virtuous cycle & HD-lopsided \\
\hline Costa Rica & HD-lopsided & HD-lopsided & Virtuous cycle & Virtuous cycle \\
\hline Dominican Republic & Vicious cycle & EG-lopsided & EG-lopsided & EG-lopsided \\
\hline Ecuador & Vicious cycle & EG-lopsided & Virtuous cycle & HD-lopsided \\
\hline El Salvador & Vicious cycle & Vicious cycle & Vicious cycle & EG-lopsided \\
\hline Guatemala & Vicious cycle & Vicious cycle & Vicious cycle & Vicious cycle \\
\hline Guyana & - & HD-lopsided & HD-lopsided & Virtuous cycle \\
\hline Haiti & Vicious cycle & Vicious cycle & Vicious cycle & Vicious cycle \\
\hline Honduras & Vicious cycle & Vicious cycle & Vicious cycle & Vicious cycle \\
\hline Jamaica & Virtuous cycle & HD-lopsided & Virtuous cycle & HD-lopsided \\
\hline Mexico & Virtuous cycle & Virtuous cycle & Virtuous cycle & Virtuous cycle \\
\hline Nicaragua & EG-lopsided & Vicious cycle & Vicious cycle & Vicious cycle \\
\hline Panama & Virtuous cycle & HD-lopsided & HD-lopsided & Virtuous cycle \\
\hline Paraguay & HD-lopsided & Virtuous cycle & Virtuous cycle & HD-lopsided \\
\hline Peru & Vicious cycle & Vicious cycle & Vicious cycle & Virtuous cycle \\
\hline Trinidad and Tobago & Virtuous cycle & Virtuous cycle & HD-lopsided & Virtuous cycle \\
\hline Uruguay & HD-lopsided & HD-lopsided & Virtuous cycle & Virtuous cycle \\
\hline Venezuela & HD-lopsided & HD-lopsided & HD-lopsided & HD-lopsided \\
\hline
\end{tabular}

Source: World Bank (various years)World Development Indicators; undP (various years), Human Development Report.

development. Building up human development, however, is a viable way of creating conditions for sustained growth and further improvements in human development.

It is instructive to investigate the extent to which our global econometric findings, summarized above, apply in the Latin American case, both to identify the robustness of the overall two-way connections between human development and economic growth, and to assess the strength of the specific links which make up Chains A and B. In the Latin American case, we obviously have far fewer observations to go on. Consequently, we used data for each decade and for each country (i.e., pooling time series and crosssections). The results are presented in tables 2 and 3 .

For Chain A, we examined the shortfall reductions for both life expectancy and infant mortality as possible dependent variables (columns 1 and 2 of table 2). In column 1, we see a positive, although not significant, relationship between the growth rate and an improved HDI in the 1960-2000 period, in which human development improvement is measured by life expectancy shortfall reduction. Public expenditure on education ${ }^{10}$ as a share of GDP at the beginning of each decade was positively and significantly related to life expectancy shortfall reduction. In column 2 , we see that female primary enrolment has a positive, and significant, effect on infant mortality shortfall reduction. Although we would have liked to include a variable for income distribution, data limitations meant that this would have reduced the number of observations by three quarters.

For Chain B, we found that two different measures of human development achievement at the beginning of each period (the literacy rate and the logarithm of life expectancy) were positively and significantly related to growth in per capita income. It is noteworthy that in this chain we found that the dummy for 1990 was negative and highly significant. This is a clear effect of the debt crisis, showing that human development achievements did not translate as well into growth in the 1980 s as they did in other decades. The dummy for

10 Used instead of education and health expenditure because of lack of data. 
TABLE 2

Chain A: Evidence from Latin American experience, 1960-2000a,b

(Ordinary least squares (OLS): dependent variable is the change

in human development over a decadec (e.g. 1970-1980))

(1)

Variable
Dependent variable: life expectancy shortfall reduction
(2)

Dependent variable: infant mortality shortfall reduction

Per capita GDP growth rate over the decade

(e.g. 1970-1980) x 100

$\begin{array}{rr}3.99 & 1.23 \\ (0.83) & (0.15)\end{array}$

(0.83) $\quad(0.15)$

$1.23^{\mathrm{d}}-0.25$

(1.92) $\quad(0.22)$

average over the decade (e.g. 1970-1980) x 100

Gross female primary school enrollment rate

1.42

$0.17^{\mathrm{d}}$

average over the decade (e.g. 1970-1980) x 10,000

$(0.25)$

(1.74)

Dummy for 1970's x 100

0.90

$9.80^{\mathrm{e}}$

(0.41) (2.54)

Dummy for 1980's x 100

3.22

$12.07^{\mathrm{e}}$

(1.22)

(2.63)

Dummy for 1990's x 100

$-0.53$

$9.32^{\mathrm{e}}$

(0.23)

(2.34)

Intercept x 100

$8.89^{\mathrm{d}}$

5.75

(1.71)

$(0.63)$

Number of observations

76

76

$\mathrm{R}^{2}$

0.095

0.220

Source: World Bank (various years)World Development Indicators; UNDP (various years), Human Development Report.

a For example, 1970-1980.

b The 1970 s is the omitted decade.

d Indicates significance at the $10 \%$ level.

${ }^{\mathrm{c}}$ Figures in parentheses are absolute $t$ statistics.

e Indicates significance at the $5 \%$ level.

TABLE 3

Chain B: Evidence from Latin American experience, 1960-2000

(Ordinary least squares (OLS): dependent variable is

per capita GDP growth over a decade $)^{a, b, c}$

\begin{tabular}{|c|c|c|}
\hline Independent variable & (1) & (2) \\
\hline $\begin{array}{l}\text { Literacy rate, average over the decade } \\
\text { (e.g. 1970-1980) x } 1000\end{array}$ & $\begin{array}{l}2.54^{\mathrm{d}} \\
(1.92)\end{array}$ & - \\
\hline $\begin{array}{l}\text { Log life expectancy, average over the decade } \\
\text { (e.g. 1970-1980) x } 10\end{array}$ & - & $\begin{array}{r}3.94^{\mathrm{d}} \\
(1.80)\end{array}$ \\
\hline $\begin{array}{l}\text { Average gross domestic investment (as a percentage of GDP) } \\
\text { over the decade (e.g. 1970-1980) } \times 1000\end{array}$ & $\begin{array}{l}4.20 \\
(1.05)\end{array}$ & $\begin{array}{c}4.54 \\
(1.14)\end{array}$ \\
\hline Dummy for 1970 's x 100 & $\begin{array}{l}-0.45 \\
(0.08)\end{array}$ & $\begin{array}{l}-2.05 \\
(0.36)\end{array}$ \\
\hline Dummy for 1980's x 10 & $\begin{array}{l}-3.39^{\mathrm{e}} \\
(6.10)\end{array}$ & $\begin{array}{l}-3.63^{\mathrm{e}} \\
(6.03)\end{array}$ \\
\hline Dummy for 1990's x 100 & $\begin{array}{l}-8.57 \\
(1.49)\end{array}$ & $\begin{array}{r}-11.53^{\mathrm{d}} \\
(1.75)\end{array}$ \\
\hline Intercept $\times 10$ & $\begin{array}{l}-0.55 \\
(0.53)\end{array}$ & $\begin{array}{r}-14.80^{\mathrm{d}} \\
(1.72)\end{array}$ \\
\hline $\begin{array}{l}\text { Number of observations } \\
\mathrm{R}^{2}\end{array}$ & $\begin{array}{c}84 \\
0.414\end{array}$ & $\begin{array}{c}84 \\
0.411\end{array}$ \\
\hline
\end{tabular}

Source: World Bank (various years)World Development Indicators.

a For example, 1970-1980.

b The 1970 s is the omitted decade.

c Figures in parentheses are absolute $t$ statistics.

\footnotetext{
d Indicates significance at the $10 \%$ level.

e Indicates significance at the $1 \%$ level.
} 
1999 was also significantly negative in the Chain B equations - presumably reflecting the continued impact of stabilization and adjustment on growth.

Taking the results as a whole, we find that Chain A appears to be weaker than Chain B in the Latin American context: i.e., while better human development leads to higher growth in subsequent decades, growth rates in Latin America are not significantly related to changes in human development. This may be partly due to the importance of the debt crisis in Latin America and the resulting adjustment requirements, which were often at the expense of expenditures on human development, when compared to our global results. In addition, it appears that variations in the policy setting, specifically in terms of priority ratios and factors determining the efficiency of the human development improvement function, were important in accounting for differences in human development performance. This indeed is supported by our account of specific country experiences, which follows.

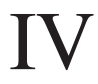

\section{Country examples of success and failure in human development and economic growth}

In this section we present thumbnail sketches of three of the good (virtuous cycle) and three of the poor (vicious cycle) performers. The aim is to identify specific circumstances and policies which appear to be responsible for such outcomes.

Chile is a country which managed good performance over the whole 40-year period, while undergoing dramatic changes in political regime and policy stance.

From the early twentieth century Chile has had a strong commitment to human development. Already in 1930 three-quarters of the adult population was literate (Thorp, 1998). In the 1960s, and in the early 1970s during the Allende administration, progress in human development was maintained through generous State expenditures on education and health. By the end of the 1960 s social expenditure amounted to $20 \%$ of GDP; primary education covered $95 \%$ of 6-14 year olds, and $81 \%$ of births were delivered by professionals (Raczynski, 1987). Growth in per capita income was modest (1.6\% per annum) over this period and egalitarian relative to the region as a whole, thus giving a human development-lopsided outcome.

Pinochet's political take-over in 1973 heralded dramatic changes in economic and social policy. Economic policy change involved a sharp move towards openness and a reduced role for the State. Over the next ten years this led to the stagnation of incomes (after an initial rise) and an increase in unemployment from $6 \%$ in the 1960 s to more than $16 \%$ by the early 1980 s. However, some of the ill effects of this on human development were offset by major employment schemes. Income distribution worsened, with the urban Santiago Gini coefficient rising from 0.47 in the 1960 s to 0.51 in $1978-1982 .{ }^{11}$ After 1986 the economy grew rapidly (the highest growth rates in Latin America), largely fuelled by expanding exports of non-traditional primary products.

From the 1960s, Chile had an extensive system of State-run welfare programmes in the areas of social security, health, and education. In addition, there was universal access to curative health care and programmes of preventive care for all expectant mothers, infants, and children less than six years of age who did not have access to alternative forms of health care. These programmes were largely maintained despite sharp cuts in aggregate social expenditure, which fell from $4 \%$ to 2\% of GDP between 1975 and 1990. Despite this reduction, Chile's human development mostly continued to improve, due mainly to more effective targeting, partly achieved through decentralization. In education, government spending focused on primary and secondary education and moved away from tertiary; indeed government expenditure on tertiary education declined from $38 \%$ of total government educational expenditure in 1980 to $19 \%$ in 1990 . The government also developed a number of special programmes and

\footnotetext{
${ }^{11}$ Riveros (1998). According to Berry (ed., 1998, p. 16), "data on the distribution of consumption among Greater Santiago households show one of the largest deteriorations ever recorded statistically in a developing country" between 1969 and 1978.
} 
subsidies designed to protect the most vulnerable members of society, especially mothers and children. These included a family subsidy for those in extreme poverty, a supplementary feeding programme for mothers and pre-school children, as well as programmes for children who fell below nutritional norms, and a school feeding programme designed to help reduce dropouts and repetitions (Raczynski, 1987). Dropout rates in government schools declined from 7\% in 1977 to $5 \%$ in 1984 . The decentralization of public health to the municipalities focused the more restricted health budget on disease prevention rather than curative medicine. Infant mortality fell from 73 per 1000 live births in 1972 to 17 in 1989.

The first ten years of the Pinochet period were thus not successful in terms of economic growth, but human development progress was maintained as a result of better targeting of the reduced social expenditures: i.e., a greatly improved priority ratio which led to human development-lopsided development. The last few years of the Pinochet regime saw a resumption of economic growth and a move towards the virtuous category.

The return to democracy in 1990 led to a renewed expansion in social expenditures and to sustained and somewhat more egalitarian economic growth. During the 1990 s, Chile's average growth rate was $4.5 \%$ per annum, compared to $2.1 \%$ during the $1980 \mathrm{~s}$ and $1.2 \%$ in the 1970s. Unemployment was reduced to low levels, and the public employment schemes could be discontinued. A progressive tax reform was introduced which helped finance the rising social expenditures. Over the 1990-1999 period, expenditure on both education and health more than doubled. Thus the 1990s saw Chile enter the virtuous category, with improved human development supported by increased growth and social expenditures; the sustained expansion in per capita GDP was, in turn, greatly facilitated by the combination of more effective economic policies and higher levels of human development.

Costa Rica, like Chile, has had a long historic commitment to human development. By 1950, its illiteracy rate was only $20 \%$, whereas the overall Latin American rate was more than $40 \%$ (Thorp, 1998). The decision in 1948 to abolish the armed forces released resources for social expenditures, which were consistently relatively high, although subject to cuts in the early 1980s. In 1988, half of government expenditure was again devoted to health and education, with nearly $30 \%$ going to priority areas.

In the 1960s and 1970s growth was fairly good (5$6 \%$ per annum). An extended welfare benefit system had nearly universal coverage. Costa Rica invested around $6 \%$ of GDP in education. Universal primary school enrolment was achieved, and secondary enrolment rose to around two-thirds, with $20 \%$ of young people between 20 and 24 in higher education, and relatively equal female and male enrolments. Adult illiteracy dropped 8 percentage points in the 1960s, and by 1980 only $13 \%$ of Costa Ricans over ten years old were illiterate, with the rate dropping still further to $4.5 \%$ by 1999 .

Improvements on health were rather slow in the 1960s, but then accelerated. About 3\% of GDP was devoted to public health expenditure in Costa Rica in 1960 , and by the end of the 1990s this had risen to more than $5 \%$, much of this increase coming in the later part of the period. Life expectancy was 67 years in 1960 , increasing to about 73 years by 1980 and 76 by $1995-2000$. Infant mortality rates remained quite high throughout the 1960s, standing at 68 per thousand in 1960 and falling slightly to 62 per thousand by 1970 , but this was followed by a significant improvement to 19 per thousand in 1980 and 12 per thousand by 1999 .

In Costa Rica, the social sector expenditure cuts of the first half of the 1980s fell most heavily on priority areas, with the share of the bottom $40 \%$ of households in educational expenditure falling from $42 \%$ in 1980 to $36 \%$ in 1986 . However, social expenditure recovered in the second half of the decade. Moreover, the minimum wage was maintained, income distribution did not deteriorate, and human development progress resumed. As a result, a virtuous cycle could be maintained.

Mexico's progress in human development came much later than Chile's or Costa Rica's. In 1960 over a third of the adult population was still illiterate. Mexico falls into the virtuous category because of its improvements in human development and economic growth during the 1960-1999 period. But the absolute standards attained were still significantly below those of Chile and Costa Rica. For example, by the end of the period life expectancy was 67 , a little less than the Latin American average (69) and much lower than Chile's (75) and Costa Rica's (77) (Thorp, 1998).

Until 1970, during the Echeverría administration, Mexico enjoyed "growth with stability," and advances were also made in human development. In the 1970s growth continued, but it was supported by heavy borrowing and rising fiscal imbalances. Mexico's economic performance was strong throughout the late 1960s and 1970s, when GDP growth averaged about 7\% overall (over $3 \%$ per capita), with manufacturing -the 
country's dominant growth sector- attracting considerable foreign investment.. Absolute poverty declined from $76 \%$ in 1960 to $45 \%$ in 1981 , but income distribution remained at unfavourable levels (Ginis between 0.5 and 0.6) (Maddison, 1992).

A central pillar of post-revolutionary government in Mexico has been a strong commitment to human development. In the 1960 s this took the form of enhanced emphasis on land reform, health, sanitation, education and nutrition. Educational expenditures averaged around $18 \%$ of total government spending in the 1970s, while those on health averaged around 5\% (IMF, various years). Good priority ratios also contributed, with primary education and vaccination programmes receiving the bulk of public spending. As a result, human development improved significantly between 1960 and 1980: life expectancy rose from 59 to 66 years; infant mortality declined from 74 to 53 per 1000 live births; adult literacy rose from $66 \%$ to $83 \%$; and gross educational enrolment almost doubled, from $106 \%$ to $120 \%$ for primary school enrolment, from $23 \%$ to $49 \%$ in the case of secondary education, and from $5 \%$ to $14 \%$ at the tertiary level.

The story in the debt-ridden 1980s was very different. Mexico cut its expenditure ratio, with a corresponding decline in human development spending, which contracted by 6\% per annum from 1983 to 1988 . Real disposable per capita income fell $5 \%$ per annum over the same period, and there were rising levels of unemployment, underemployment and poverty. The share of education in total expenditure dropped by almost $30 \%$, most of the reduction being in primary education (Friedmann, Lustig and Legovini, 1995). Teacher and student per school ratios both declined between 1983 and 1988, as did the numbers of medical units, hospital beds and doctors per capita. Despite its very poor performance in economic growth and human development, however, Mexico still did well compared with the rest of the region, though not by world standards.

After the economic reforms initiated in the late 1980s, the economy performed better, bolstered by foreign investment following the ratification of NAFTA. But financial crises in 1994 and 1998 were followed by economic contraction and social sector cutbacks. For the decade as a whole, the growth rate per capita was $1.25 \%$ per annum (following a negative average growth rate in the 1980s). In the early part of the 1990s there was an increase in the share of GDP going to the social sectors, and expenditures on education rose by 90\% between 1989 and 1993, while those on health increased by $79 \%$. There was a reduction in general food subsidies, with a rise in (somewhat ineffective) targeting. A large-scale programme called PRONASOL was established to make social expenditure more costeffective and foster greater community involvement. One of its components, called "Solidaridad" contained a wide range of social programmes, including education and health, but has been accused of being politically manipulated by the then ruling party. These factors may account for the fact that Mexico shifted into the economic growth-lopsided category in the 1990s. The programme was renamed PRONOSOL and restructured in 1995, becoming less political.

In summary, Mexico's inclusion in the virtuous category in the 1960s and 1970s was due to its economic growth and social expenditure. Another element supporting human development has been the improvement in gender roles with the greater institutionalization of women's rights. The somewhat inferior performance in human development in the 1990s was probably due to inappropriate targeting, cutbacks following the crises, and the problems inherited from the 1980s.

From 1960 to 1970, Jamaica was in a virtuous cycle, the result of rapid economic growth at more than $6 \%$ per annum, combined with a strong government commitment to human development, with social expenditures increasing from 5.6\% of GDP in 1960 to $12.2 \%$ in 1975 . Primary school enrolment expanded from $65 \%$ to $85 \%$ during the 1960 s, while secondary enrolment rose from $15 \%$ to $58 \%$. By 1970 , life expectancy in Jamaica was 68 years and the literacy rate was $86 \%$, both well above the regional average (Thorp, 1998). However, severe economic problems and tough adjustment programmes subsequently led to a deterioration in human development performance, pushing Jamaica into the vicious cycle category for much of the rest of the period.

During the 1970s severe external terms of trade shocks led to economic contraction, with sharp cutbacks in social expenditures in order to comply with the financial recommendations of the IMF. This deterioration in human development expenditures continued in the 1980 s, with stringent adjustment policies which included a reduction in real expenditure on education and health by $30 \%$ between 1980 and 1986 (World Bank, 1984). The human development priority ratio also worsened, though expenditures on tertiary education were relatively protected. General food subsidies were replaced with targeted ones, and there was a deterioration in nutrition. Income distribution worsened and poverty increased. 
Jamaica's economy recovered in the latter part of the 1980 s, with a $2.4 \%$ per annum increase in per capita GDP between 1986 and 1990, but this was not translated into social expenditures, as there was a fall in their share as a percentage of GDP. However, they recovered in the early 1990s, when public health expenditures reached $3.2 \%$ of GDP in 1995, and public education expenditure $5.4 \%$.

Jamaica continued to be a rather poor performer on the economic front in the 1990s. Average per capita GDP growth was negative in the 1990s (about $-0.6 \%$ per annum between 1990 and 1999, compared to $+0.3 \%$ per annum in the previous decade). However, human development indicators showed a substantial improvement in the 1990's, which may result in future improvements in Jamaica's economic growth performance. By the end of the 1990's life expectancy in Jamaica was about 75 years, the adult literacy rate $86 \%$, gross primary enrolment rate $98 \%$, and gross secondary enrolment rate $90 \%$. Infant mortality was down to 20 per 1000 live births.

The case of Guyana is similar to that of Jamaica, only more so, with weak economic performance undermining human development from as early as the 1960s, subsequently aggravated by adjustment programmes which included social expenditure cuts. There was some economic recovery in the 1990s, but this was not accompanied by substantial human development improvements.

Guyana started off the period with a relatively low life expectancy of about 60 years in 1960 and a high infant mortality rate of about 99 per 1000 . After independence in 1966, there was an initial period of significant growth in GDP and in social expenditures. For example, education expenditure grew by over $60 \%$ in the 1970-1975 period, and health spending rose by over $40 \%$. Primary and secondary enrolment rates also increased. In the 1970 s, the government greatly expanded its ownership of the economy, and an estimated $80 \%$ of the formal sector was under government control. Near-permanent economic crisis followed the early expansion, due to a combination of external circumstances (worsening terms of trade) and internal mismanagement. Between 1975 and 1983, the decline in GDP exceeded the previous expansion. Growth in per capita GDP over the 1970s as a whole averaged about $0.7 \%$ per annum. In the 1980 s, external crises and internal mismanagement continued; the government takeover of the bulk of the retailing and distribution systems was associated with large declines in productivity. Rationing of foreign exchange and import controls led to shortages of production inputs, and the poor state of the infrastructure further handicapped the economy, which regressed in the 1980 s, with an annual fall in per capita incomes of $3.9 \%$. The cumulative loss in GDP over the 1980s was $28 \%$. The crises also led to cuts in social expenditures, which fell as a proportion of total government expenditure. In 1988 expenditure on education constituted only $6.4 \%$ of total government expenditure and expenditure on health $3.7 \%$.

In the $1990 \mathrm{~s}$, macro policies changed as the government liberalized foreign exchange regulations, lifted price controls and import prohibitions and encouraged private investment. This was followed by a growth spurt: in the 1990s, per capita GDP grew at an average annual rate of $4.2 \%$ between 1990 and 1999 (well above the regional average). However, human development still lagged behind: life expectancy in Guyana in 1999 was only about 64 years (compared with a regional average of about 70 years) and infant mortality rates continued to be high at about 57 deaths per 1000 live births (compared with a regional average of 31). However, public expenditures on health and education began to show some improvement as from 1990: public expenditure on health was about $9 \%$ of GDP by the end of the decade and public expenditure on education reached $8 \%$ of total government expenditure.

Nicaragua's experience falls into three distinct periods: the Somoza era, covering the 1960s and 1970s; the Sandinista revolution and subsequent government, which was accompanied by continuous civil war; and the post-war period of the 1990s. Nicaragua was one of the last countries in Latin America to make any substantial progress in human development. Over half the adult population was illiterate in 1960, and life expectancy was only 47 years (Thorp, 1998).

During the Somoza era there were high rates of growth, but this was very unequally distributed. The Somozas themselves owned or controlled $60 \%$ of national economic activity. And social expenditure was low as well as unequally distributed. By the late 1970s only $65 \%$ of primary school age children were enrolled in school and only $22 \%$ completed the full six years of primary education. Three-quarters of the rural population was illiterate. Infant mortality rates were around 100 per 1,000 live births. Between 1965 and 1975 the number of children under five suffering from malnutrition doubled, at a time when GDP also doubled.

Economic growth was sharply disrupted by the revolution of 1979, with GDP shrinking by a quarter in 
that year. The Sandinistas had a strong commitment to expansion of social expenditures and to improving the distribution of assets and incomes. In the early years of their regime, in 1980 and 1981, GDP jumped by 5\%, and there was a big expansion in social expenditure and social service coverage. The proportion of GDP spent on primary and secondary education doubled, and adult illiteracy was reduced from $50 \%$ to $23 \%$. The health sector expanded greatly, with an emphasis on preventive and primary care, targeting the principal causes of infant, child and maternal mortality, providing broader coverage, and eliciting higher levels of community participation. In both health and education, therefore, there were favourable priority ratios. Both health and education outcomes showed improvements: Nicaragua's life expectancy in 1980 was about 59 years (compared to 47 years in 1960) and gross primary enrolment was about $94 \%$ (compared to $66 \%$ in 1960).

However, GDP dropped every year from 1984 to1990, with a cumulative drop of over $40 \%$ for the decade, as a consequence of the civil war, the US trade embargo and the reluctance of foreign banks to invest. Inflation spiralled, and the situation was further aggravated by natural disasters, including hurricanes and drought. By 1990 per capita income was below that of the 1970 s, and in the ensuing decade per capita GDP fell by $4.1 \%$ per annum.
The economic collapse and disruptions caused by the war eventually undermined the social sectors, despite the Sandinistas' efforts. The literacy rate, for example, fell back to the levels of the late 1970s, and the infant mortality rate, which had gone down to 63 per 1000 during the early Sandinista years, began to rise again and reached 72 per 1000 in 1989.

The post-war era of the 1990s was dominated by debt and adjustment problems, as well as natural disasters, including a drought and hurricane. Economic recovery never really got under way, and social expenditures were subject to cuts. In the 1990s growth rates of per capita GDP were barely positive, at $0.3 \%$ per annum between 1990 and 1999.

In summary, the Somoza years illustrate how good economic growth can fail to translate into human development when it is badly distributed, with unequal income and asset distribution and low social expenditures accompanied by poor priority ratios. In contrast, the Sandinista period greatly improved human development initially, by better distributed and higher levels of social expenditure, but this was negated by the effects of the civil war, the embargo and natural disasters. The post-war era suffered from the problems of war debt, inadequate finance, and stringent adjustment policies.

\section{V}

\section{Some conclusions}

The Latin American region as a whole has been marked by relatively high levels and improvements in human development compared with the global developing world average during the period from 1960 to 2000, but its performance in terms of economic growth has not been so good. Latin American life expectancy at the start of the period, in 1960, was substantially higher than in the rest of the developing world. This may well be due to the region's much earlier political independence and consequently greater commitment to human development, particularly for the elite. At the same time, it was the region with the highest degree of inequality in income distribution (Berry, 1998).

Our efforts to estimate the strengths of various links in Chains A and B indicate that the links from economic growth to human development (i.e., Chain A) are more variable in Latin America than those we found on the world scene. The social expenditure ratio holds up well, but GDP growth did not systematically translate into human development improvement in a significant way, indicating that there were country-specific circumstances which affected the strength of the chain. The links in Chain B, running from human development to economic growth, on the other hand, showed themselves to be closer to the global results, with initial human development levels significantly affecting economic growth. For both chains we were constrained in what we could test because of the more limited country data availability for some variables and fewer country observations.

Our country cases illustrate how specific circumstances influenced the strength of various links 
in chains A and B. We studied three countries which fell in the virtuous quadrant over the period taken as a whole (Chile, Costa Rica and Mexico), and three which fell into the vicious quadrant (Guyana, Jamaica and Nicaragua).

With respect to the three successful cases, high growth accompanied by high social expenditure ratios translated into human development improvements, as in Mexico in the 1960s and 1970s, and Chile in the 1960s. An alternative path to success, illustrated by Costa Rica, involved moderate and relatively well distributed growth, accompanied by very high social expenditure ratios, with good priority ratios. Chile in the middle period (1975-1990) illustrates a third path to success, characterized by very well targeted social expenditures, with uneven growth for much of the period and only moderate social expenditure ratios. Later, Chile fell into the high growth and good social expenditure ratio category.

There are clearly also many paths to failure. Growth accompanied by very poor distribution of both private income and social services served to weaken chain A substantially in the case of Nicaragua during the Somoza period. Severe economic shocks and a failure to protect social sectors during adjustment accounted for the relative failure of human development in Jamaica in the 1980s, in Guyana for much of the period under consideration, and in Nicaragua during the 1990s. Civil war and a trade embargo were also important in undermining human development improvement in Nicaragua in the 1980s, while natural disasters were a problem in every decade. Heavy external debt, accumulated as a result of war in the case of Nicaragua, also stymied human development efforts in post-war Nicaragua and in Guyana in both the 1980s and 1990s.

Exploration of how countries behaved decade by decade (see table 1) confirms the view, reached earlier on a global basis, that human development must necessarily be promoted in order to reach a virtuous cycle of growth and human development improvement. No Latin American country moved from an economic growth-lopsided position to a virtuous position. Our regressions for Latin America tell the same story: i.e., human development improvements do lead to economic growth improvements, although in this case economic growth improvements did not systematically generate advances in human development. Our regional findings therefore also contradict the usually recommended policy sequence, namely, that growth should be generated first, and that human development will naturally follow. Ending on an optimistic note, the recent surge in social sector expenditures in Latin America in the 1990s may well pave the way for improved growth in the present decade, in contrast with the cuts of the 1980s, which handicapped both growth and hence also human development.

(Original: English)

\section{Bibliography}

Ainsworth, M., K. Beegle and A. Nyamete (1995): The Impact of Female Schooling on Fertility and Contraceptive Use: A Study of Fourteen Sub-Saharan Countries, LSMS working paper, No. 110, Washington, D.C., World Bank.

Alesina, A. and D. Rodrik (1994): Distributive politics and economic growth, Quarterly Journal of Economics, vol. 109, No. 2, Cambridge, Massachusetts, MIT Press.

Alesina, A. and R. Perotti (1994): The political economy of growth: A critical survey of the recent literature, The World Bank Economic Review, vol. 8, No. 3, Washington, D.C., World Bank.

Barro, R. (1991): Economic growth in a cross section of countries, Quarterly Journal of Economics, vol. 106, No. 2, Cambridge, Massachusetts, MIT Press.

Barro, R. and J. Lee (1993a): International comparison of educational attainment, Journal of Monetary Economics, vol. 32, No. 3, Amsterdam, The Netherlands, North-Holland Publishing Company.

(1993b): Losers and winners in economic growth, in World Bank, Proceedings of the World Bank Annual Conference on Development Economics, 1993, Washington, D.C., World Bank.
Behrman, J. R. (1993): The economic rationale for investing in nutrition in developing countries, World Development, vol. 21, No. 11, Oxford, U.K., Pergamon Press.

(1994): Intrafamily distribution in developing countries, Pakistan Development Review, No. 33, Islamabad, Pakistan, TGE Pakistan Institute of Development Economics.

1996): The impact of health and nutrition on education, The World Bank Research Observer, vol. 11, No. 1, Washington, D.C., World Bank.

Berry, A. and M. Urrutia (1976): Income Distribution in Colombia, New Haven, Yale University Press.

Berry, A. (ed.) (1998): Poverty, Economic Reform and Income Distribution in Latin America, Boulder, Colorado, Lynne Rienner.

Birdsall, N., D. Ross and R. Sabot (1995): Inequality and growth reconsidered: Lessons from East Asia, The World Bank Economic Review, vol. 9, No. 3, Washington, D.C., World Bank.

Edwards, S. (1993): Openness, trade liberalization, and growth in developing countries, Journal of Economic Literature, vol. 31, No. 3, Nashville, Tennessee, American Economic Association. 
Foster, A. D. and M. R. Rosenzweig (1994): Technical change and human resources and investments: Consequences of the green revolution, Philadelphia, Pennsylvania, University of Pennsylvania, unpublished.

(1995): Learning by doing and learning from others: Human capital and technical change in agriculture, Journal of Political Economy, vol. 103, No. 6, Chicago, Illinois, The University of Chicago.

Friedmann, S., N. Lustig and A. Legovini (1995): Mexico: Social spending and food subsidies during adjustment in the 1980s, in N. Lustig (ed.), Coping with Austerity: Poverty and Inequality in Latin America, Washington, D.C., The Brookings Institution.

IMF (International Monetary Fund) (several years): Government Finance Statistics Yearbook, Washington, D.C.

Krueger, A. (1978): Foreign Trade Regimes and Economic Development: Liberalization Attempts and Consequences, Cambridge, Massachusetts, Ballinger.

Maddison, A. (1992): The Political Economy of Poverty, Equity and Growth: Brazil and Mexico, Washington, D.C., World Bank.

Michaely, M. (1977): Exports and growth: An empirical investigation, Developing Economics, vol. 4, No. 1, Amsterdam, The Netherlands, North-Holland.

Persson, T. and G. Tabellini (1994): Is inequality harmful for growth?, The American Economic Review, vol. 85, No. 2, Nashville, Tennessee, American Economic Association.

Psacharopoulos, G. (1994): Returns to investment in education: A global update, World Development, vol. 22, No. 9, Oxford, U.K., Pergamon Press.

Psacharopoulos, G. and others (1992): Poverty and Income Distribution in Latin America: The Story of the 1980s, Washington, D.C., World Bank.

Raczynski, D. (1988): Social policy, poverty and vulnerable groups: Children in Chile, in G. Cornia, R. Jolly and F. Stewart (eds.), Adjustment with a Human Face, vol. 2, Oxford, U.K., Clarendon Press.

Ram, R. (1985): Exports and economic growth: Some additional evidence, Economic Development and Cultural Change, vol. 33, No. 2, Chicago, Illinois, The University of Chicago Press.

Rana, P. (1988): Exports, policy changes and economic growth in developing countries after the 1973 oil shock, Developing
Economics, vol. 28, No. 3, Amsterdam, The Netherlands, North-Holland.

Ranis, G., F. Stewart and A. Ramírez (2000): Economic growth and human development, World Development, vol. 28, No. 2, Oxford, U.K., Pergamon Press.

Riddell, R. and others (1995): Non-governmental Organizations and Rural Poverty Alleviation, New York, Oxford University Press.

Riveros, L. (1998): Chile's structural adjustment: Relevant policy lessons for Latin America, in A. Berry (ed.), Poverty, Economic Reform and Income Distribution in Latin America, Boulder, Colorado, Lynne Riener.

Rosenzweig, M. R. (1995): Why are there returns to schooling?, The American Economic Review, vol. 85, No. 2, Nashville, Tennessee, American Economic Association.

Schultz, T. W. (1975): The value of the ability to deal with disequilibria, Journal of Economic Literature, vol. 13, No. 3, Nashville, Tennessee, American Economic Association.

Schultz, T. P. and A. Tansel (1993): Measurement of Returns to Adult Health, LSMS working paper, No. 95, Washington, D.C., World Bank.

Thorp, R. (1998): Progress, Poverty and Exclusion: An Economic History of Latin America in the 20th Century, Baltimore, Maryland, The Johns Hopkins University Press.

UNDP (United Nations Development Programme) (1990): Human Development Report 1990, New York, Oxford University Press.

(1991): Human Development Report 1991, New York, Oxford University Press.

(2001): Human Development Report 2001, New York, Oxford University Press.

Welch, F. (1970): Education in production, Journal of Political Economy, vol. 78, No. 1, Chicago, Illinois, The University of Chicago Press.

Wood, A. (1994): North-South Trade, Employment and Inequality: Changing Fortunes in a Skill-Driven World, Oxford, U.K., Oxford University Press.

World Bank (1984): Trends in Developing Economies, Washington, D.C.

(2001): World Development Indicators 2001, Washington, D.C. 